\title{
Internal Marketing and Customer Loyalty: A Dyadic Analysis
}

\author{
Hayat Muhammad Awan1, Ahmad Nabeel Siddiquei1', Aneela Jabbar1, Muhammad Abrar2*, \\ Sajjad Ahmad Baig2 \\ ${ }^{1}$ Department of Business Administration, Air University, Multan Campus, Multan, Pakistan \\ ${ }^{2}$ Department of Business Administration, National Textile University, Faisalabad, Pakistan \\ Email: *abrarphd@gmail.com
}

Received 11 March 2015; accepted 6 April 2015; published 8 April 2015

Copyright (C) 2015 by authors and Scientific Research Publishing Inc.

This work is licensed under the Creative Commons Attribution International License (CC BY). http://creativecommons.org/licenses/by/4.0/

c. (i) Open Access

\begin{abstract}
The purpose of this paper is to investigate the effects of internal marketing on customer loyalty and the mediating role of job satisfaction, affective commitment $\&$ organizational citizenship behaviour in their relationship. The analysis is based on a dyadic data set of front-end service employees and customers. It involves responses provided by the $\mathbf{1 5 0}$ dyads collected through quantitative self-administered questionnaires from telecommunication organizations of Pakistan. Findings demonstrate that internal marketing has a positive significant effect on job satisfaction, affective commitment and organizational citizenship behaviour. Furthermore, the theoretical model shows that organizational citizenship behaviour, affective commitment and job satisfaction act as mediators between internal marketing and customer loyalty. This study implies that IM is very beneficial and effective approach towards the customer positive behavioural outcomes such as customer loyalty.
\end{abstract}

\section{Keywords}

Internal Marketing, Job Satisfaction, Affective Commitment, Organizational Citizenship Behaviour, Customer Loyalty

\section{Introduction}

The notion of internal marketing (IM) encompasses many of the human resource policies such as attracting, selecting, training, motivating, directing, evaluating and rewarding the employees [1]. The role that internal marketing plays in service organizations may be particularly important in telecommunication organizations. Recently, Khalid \& Mughal [2] have examined the internal marketing techniques undertaken by telecom organiza-

${ }^{*}$ Corresponding author.

How to cite this paper: Awan, H.M., Siddiquei, A.N., Jabbar, A., Abrar, M. and Baig, S.A. (2015) Internal Marketing and Customer Loyalty: A Dyadic Analysis. Journal of Service Science and Management, 8, 216-228.

http://dx.doi.org/10.4236/jssm.2015.82024 
tions in Pakistan. Telecom organizations in Pakistan have expanded budgets to invest in the continual improvement of their human resource functions so as to obtain better outcomes in terms of satisfied, motivated, and determined workforce. They have well established recruitment and selection programs, training and development facilities, performance appraisal and rewards systems, career development programs and compensation management systems.

Studies on the internal marketing pertaining to service industry revealed some interesting outcomes. Ahmed et al. [3] studied the influence of several internal marketing practices such as employee training, internal communication, incentives, inter-functional coordination etc. on the employee job satisfaction. They validated a significant positive association between the internal marketing and job satisfaction. Hogg [4] asserted that internal marketing helped in developing organizational commitment among the employees and internal marketing was considerably linked to the affective component of organizational commitment [5]. Internal marketing also helps organizations to develop organizational citizenship behavior among employee [6]. So, if internal marketing is successfully implemented in organization, its employees develop very positive attitude towards work and put their maximum efforts to get the job done. In addition to it, this has also been found that satisfied employees are more likely to be committed to their organization [7] and exhibit citizenship behavior [8] [9].

The subject of relationship between customer-contact employees and customers has remained a focus of many researchers particularly relating to services industry [10]-[12]. Existing literature indicates that this employeecustomer interaction affects customer loyalty [12]. The attitude of employees, their skills, equipment and available support they need in delivering the services, all are determinants of customer loyalty [13]. Previously many studies investigated the influence of various organizational variables on customer reactions [14]. However, no particular study determined the relationship of internal marketing with customer positive behavioral outcomes such as customer loyalty. So, the present study examines two research questions:

The purpose of this study is twofold:

1) What is the relationship between internal marketing and customer loyalty?

2) Determine the mediating roles of job satisfaction, affective commitment and organizational citizenship behaviour in the relationship between internal marketing and customer loyalty.

\section{Theory Development}

\subsection{Internal Marketing, Job Satisfaction and Customer Loyalty}

Existing literature reveals that internal marketing is the most effective tool to enhance employee job satisfaction [15]. Research in the field of job satisfaction has indicated that job satisfaction depends on following organizational variables: pay, structure, size, leadership, working conditions which denote the culture of organization [16]. It has remained a concern of many researchers to find the link between the internal marketing and job satisfaction [17]. When an organization performs internal marketing activities, it is actually elevating the job satisfaction level of its employees [18]. Internal marketing has a significant positive impact on job satisfaction [19]. A study has been done to find the impact of four dimensions of internal marketing which are employees' training \& development, motivation, communication and empowerment. All these four dimensions have a positive effect on employee's job satisfaction [20]. In the light of above literature, this study has also attempted to test the effect of internal marketing on the job satisfaction of employees.

Harvard Business School (HBS) developed a term named, the "service profit chain". Schlesinger \& Zornitsky [21] provided the evidence of association between employee satisfaction and customer satisfaction. This positive relation is also supported by many other authors [22] [23]. Boulding et al. [24] found the positive association between the satisfied customers and loyal customers. As the previous literature on services marketing supports that employee satisfaction leads to customer satisfaction which in turn generates customer loyalty, it is justified to say that employee job satisfaction contributes towards customer loyalty. The present research study is aimed to study the association between job satisfaction and customer loyalty.

H1: Internal marketing has a significant positive effect on job satisfaction.

H2: Job satisfaction has a significant positive effect on customer loyalty.

H3: Job satisfaction mediates the relationship between internal marketing and customer loyalty.

\subsection{Internal Marketing, Affective Commitment and Customer Loyalty}

It has been indicated in the previous study that the market orientation of a company is only significantly related 
to the affective dimension of the organizational commitment [5]. Marketing orientation is similar to internal marketingin the context that it involves those actions that are taken within the organization. Several antecedents of organizational commitment are found in the psychology literature. Mathieu and Zajac [25] have suggested five of them which are: job characteristics, role states, organizational characteristic, personal relations and group/leader relations. Similarly, organizational commitment is linked to job performance in terms of consequences [25]. But at the same time, increased job satisfaction and decrease in employee turnover were found to be significantly related to affective dimension of organizational commitment [26]. Affective component of organizational commitment is more comprehensively discussed in the field of services marketing. It has been highlighted in a study that internal marketing plays an important role in developing organizational commitment but more notably, the literature suggests the impact of internal marketing on the affective element of organizational commitment [27]. It is also noted in the previous studies that organizational commitment is identified in its affective conceptualization [28]. Therefore the present study is aimed to study the effect of internal marketing on the affective component of organizational commitment.

With the increase in attachment of employees with their organization, the chances of customer attachment also increases [29]. Reichheld [30] suggested that the employees who lack loyalty to their organization are highly unlikely to build the inventory of loyal customer. McCarthy [31] provided suggestions that how any organization can enhance the customer loyalty by making their employees loyal. Allen \& Grisaffe [32] proposed that the employees who are affectively committed to the organization are expected to involve in positive customer pertinent behavior than those who lack affective commitment. They further proposed that this relationship is stronger with those employees who have substantial customer interaction. Several researches have supported the relation between employee attitudes and customer reactions [31] [33]. However, no research has been done to study the relationship between affective commitment and customer loyalty.

H4: Internal marketing has a significant positive affect on effective commitment.

H5: Affective commitment has a significant positive effect on customer loyalty.

H6: Affective commitment mediates the relationship between internal marketing and customer loyalty.

\subsection{Internal Marketing, Organizational Citizenship Behaviour and Customer Loyalty}

Many authors have mentioned various antecedents of Organizational Citizenship Behaviour; these include leader-member exchange [34], transformational leadership [35], procedural justice discernments [36], nature, commitment, and job satisfaction of the individual [37], confidence in supervisor [38]. Some researchers have also indicated that satisfied employees who feel job security in the organization will establish organizational citizenship behavior [39]. Previously, the influential role of internal marketing on organizational citizenship behavior was overlooked by the authors. Wherever it was indicated that internal marketing helps organizations to develop organizational citizenship behavior among its employees (Seyed Javadin et al., 2012). For these reasons, the effect of internal marketing on organizational citizenship behavior has been examined.

Whatever activities employees perform in a service organization connect its organization to the customers [40]. Such activities helps in fulfilling the promises made to the customers and thereby maintain customer loyalty [41]. These employees' actions are of high importance in developing successful employee-customer associations [42]. Thus employees responsible for delivering the quality services to meet the customers' expectations [43]. The attitude of employees, their skills, and the other available support they need in delivering the service, all are the determinants of the customer loyalty [13] [44]. Many studies were aimed to find the influence of these organizational variables on customer reactions [14]. Nevertheless, all the existing studies have focused on the in-role behavior of employees. The current study is conducted to extend the previous researches and focus on the complex relationships that's exists between organizational citizenship behavior and customer loyalty.

H7: Internal marketing has a significant positive effect on organizational citizenship behavior.

H8: Organizational citizenship behavior has a significant positive effect on customer loyalty.

H9: Organizational citizenship behaviormediates the relationship between internal marketing and customer loyalty.

\subsection{Job Satisfaction, Affective Commitment and Organizational Citizenship Behavior}

Kotze \& Roodt [45] indicated a strong positive link between job satisfaction and employee commitment. A positive association between the job satisfaction and affective commitment suggested that employee satisfaction in 
terms of their promotion, pay, supervision, contingent with co-workers leads to strong emotional attachment and involvement with their organization [46]. These findings are in line with those of Spector [47] where employee are attributed to the fact that both affective commitment and job satisfaction are related to the individual's attitude towards their job work. In view of this apparent relationship, this research also examines the effect of job satisfaction on affective commitment.

H10: Job satisfaction has a significant positive effect on affective commitment.

Job satisfaction is positively associated with employee organizational citizenship behavior [9]. This relationship is underpinned by two theories: the theory of psychological contract [48] and the theory of social exchange [38]. Both theories explain the "reciprocity rule": a satisfied employee reciprocates organizational citizenship behavior towards those employees who have preferred or helped him [8].

H11: Job satisfaction has a significant positive effect on organizational citizenship behaviour.

Figure 1 shows research model that depicts the relationships between internal marketing, its outcomes and customer loyalty. In total, eleven hypotheses are proposed regarding this model.

\section{Research Methodology}

\subsection{Sampling and Data Collection}

Telecom operators have company owned customer care centers which are also known as walk in centers to provide services to the customers. These services are delivered by the customer service officers known as CSOs who interact with the customers face to face. Only customer care centers are made part of this study because the HR and marketing policies of telecom organizations have direct impact on the jobs of CSOs as they are at company's payroll whereas franchises and sales centers are excluded. The CSOs deal with the issues and problems that customers encounter while using the telecom network and other value added services, therefore they play very critical role in generating customer's responses towards the service and organization. CSOs and the customers who avail services from them together are considered as the employee-customer dyad which is unit of analysis for this research. In order to test the proposed hypothesis, two self-administered questionnaires were developed to collect data from employee-customer dyad. This methodology has been previously used by various authors in their study of internal marketing [6] [49]. Both questionnaires were distributed in five big cities of Pakistan which are Karachi, Islamabad, Lahore, Multan and Faisalabad. There are 44 customer care centers in these five big cities of Pakistan, out of which only 30 were selected to give equal weightage to each city and telecom operator. Every telecom operator has at least two customer care centers in Karachi, therefore, two customer care centers of each telecom operator is selected from Karachi. Remaining cities have at least one customer care center so one customer care center is selected from each of these four cities. In all the customer care centers, there were at least five and at most nine CSOs working at a time. The CSOs and customers were selected for data collection using convenience sampling technique. The CSO who had momentarily less workload

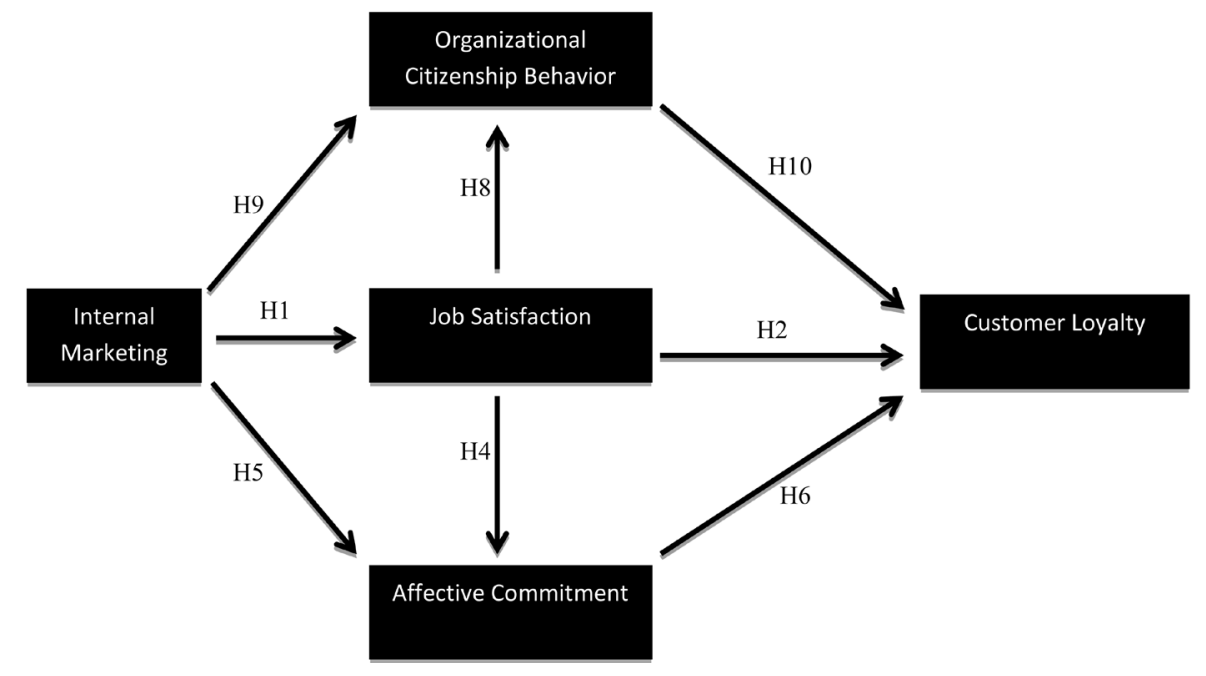

Figure 1. Theoretical framework. 
was handed over the questionnaire and the customer who had just received service from that CSO was selected to gather the data. For every CSO, only one customer was selected and treated as one observation. In total, 150 observations were collected from those employees and customers who have been providing and availing the services for at least last one year. Among CSOs, the population break out on the basis of gender was $62.7 \%$ male and $37.3 \%$ female. The customer population breakout on the basis of gender was $74.7 \%$ males and $25.3 \%$ females. In females, the customers were mostly housewives. Whereas males belong to different backgrounds such as college or university students, jobholders, businessmen and professionals like lawyers, and doctors.

\subsection{Measures}

All measures employed in this research work were based on the in-depth study of services marketing literature. Seven points likert scale was used with anchors of strongly agree (1) and strongly disagree (7). The CSO's provided evidence for the four constructs which are internal marketing, job satisfaction, affective commitment and organizational citizenship behavior where as customers reported on customer loyalty construct. The internal marketing scale is adapted from the research by Foreman and Money [50]. They suggested vision, development and reward as three dimensions of internal marketing which are measured by 16 items scale. Job satisfaction scale is adapted from Spector [51] that examines eight facets of job (pay, promotion, supervision, fringe benefits, contingent rewards, operating conditions, co-workers, nature of the work, and communication). Meyer \& Allen [52] seven items affective commitment scale is adapted. Investigating earlier works [53] [54], three dimensions of organizational citizenship behavior which are measured by nine items scale are included in this study. These three dimensions which are altruism, sportsmanship, and civic virtue reveal those behaviors of employees that affect the employee-customer dealings [55]. Customer loyalty four items scale is adapted from the research work of Amy, W. and S. S. Amrik [12].

\section{Results}

\subsection{Confirmatory Factor Analysis}

CFA was applied confirmed four constructs comprised of 40 items having on extraction (AVE) and Cronbach's Alphas above the recommended points [56]. The results are shown in Table 1. Additionally, this study uses chisquare, goodness of fit index (GFI), adjusted goodness of fit index (AGFI) and root mean square residual (RMR) to evaluate the fitness of the full model. The chi-square value $\left(\chi^{2}\right)$ of 1802.02 with degrees of freedom (d.f.) of 901 is statistically significant at 0.005 significance level. However, the chi-square test becomes more sensitive with increasing number of indicators. A ratio of $\left(\chi^{2} /\right.$ d.f. $\left.=2.00\right)$ is acceptable. Bearing this in mind, other measures are further examined. The results show an excellent model fit with values of: GFI $=0.972$, AGFI $=0.938$ $\mathrm{RMR}=0.018$.

\subsection{Correlation Analysis}

AHP introduced by Wind and Saaty [57] is a multi-criteria decision making technique used to prioritize the alternatives for decision making [58]. Pearson correlation was applied on the global priority weights found by AHP to measure the individual contribution of items towards the overall weight of customer loyalty. The resulting outcomes explained in Table 2 depict that the major contributor towards customer loyalty is OCB $(r=0.036$, $p=0.000)$. Second contributor towards customer loyalty is "job satisfaction" ( $\mathrm{r}=0.005, p=0.000)$ of customer service employees. The results further show that the maximum contribution towards organizational citizenship behavior is coming from "job satisfaction" ( $\mathrm{r}=0.747, p=0.000)$. Internal marketing $(\mathrm{r}=0.500, p=0.000)$ is the second contributor in developing organizational citizenship behavior among employees. These findings are in line with the findings of many other authors that organizational citizenship behavior is enhanced by job satisfaction [59] [60] \& internal marketing [6]. The results further show that the maximum contribution towards affective commitment is coming from "job satisfaction" $(\mathrm{r}=0.635, p=0.000)$. Internal marketing $(\mathrm{r}=0.500, p=$ 0.626 ) is the second contributor in developing affective commitment among employees. These findings are in line with the findings of many other authors that affective commitment is enhanced by job satisfaction [46] and internal marketing [27] [61]. The sole contributor towards job satisfaction is "internal marketing" ( $\mathrm{r}=0.679, p=$ 0.000). This finding is in line with the finding of [17]. 
Table 1. Confirmatory factor analysis.

\begin{tabular}{|c|c|c|c|c|c|c|}
\hline & & IM & JS & AC & ОСВ & CL \\
\hline \multirow{3}{*}{ IM } & Pearson correlation & 1 & & & & \\
\hline & Sig. (2-tailed) & & & & & \\
\hline & $\mathrm{N}$ & 150 & & & & \\
\hline \multirow{3}{*}{ JS } & Pearson correlation & $0.679^{* *}$ & 1 & & & \\
\hline & Sig. (2-tailed) & 0.000 & & & & \\
\hline & $\mathrm{N}$ & 150 & 150 & & & \\
\hline \multirow{3}{*}{ AC } & Pearson correlation & $0.626^{* *}$ & $0.635^{* *}$ & 1 & & \\
\hline & Sig. (2-tailed) & 0.000 & 0.000 & & & \\
\hline & $\mathrm{N}$ & 150 & 150 & 150 & & \\
\hline \multirow{3}{*}{ OCB } & Pearson correlation & $0.500^{* *}$ & $0.528^{* *}$ & $0.498^{* *}$ & 1 & \\
\hline & Sig. (2-tailed) & 0.000 & 0.000 & 0.000 & & \\
\hline & $\mathrm{N}$ & 150 & 150 & 150 & 150 & \\
\hline \multirow{3}{*}{ CL } & Pearson correlation & 0.127 & 0.005 & 0.034 & 0.036 & 1 \\
\hline & Sig. (2-tailed) & 0.120 & 0.000 & 0.000 & 0.000 & \\
\hline & $\mathrm{N}$ & 150 & 150 & 150 & 150 & 150 \\
\hline
\end{tabular}

${ }^{*} \mathrm{IM}=$ internal marketing, $\mathrm{JS}=$ job satisfaction, AC = affective commitment, OCB = organizational citizenship behavior, CL = customer loyalty.

Table 2. Correlation analysis.

\begin{tabular}{|c|c|c|c|c|c|c|c|}
\hline & Relation & & & Estimate & S.E. & $p$ value & Results \\
\hline Job satisfaction & $\leqslant=$ & Internal marketing & $\mathrm{H} 1$ & 1.077 & 0.095 & $* * *$ & Supported \\
\hline Customer loyalty & $\ll=$ & Job satisfaction & $\mathrm{H} 2$ & 0.097 & 0.097 & 0.004 & Supported \\
\hline Affective commitment & $\leqslant=$ & Job satisfaction & $\mathrm{H} 4$ & 0.322 & 0.067 & $* * *$ & Supported \\
\hline Affective commitment & $\leqslant=$ & Internal marketing & H5 & 0.474 & 0.106 & $* * *$ & Supported \\
\hline Customer loyalty & $\leqslant=$ & Affective commitment & H6 & 0.167 & 0.109 & 0.033 & Supported \\
\hline Organizational citizenship behavior & $\ll=$ & Job satisfaction & H8 & 0.203 & 0.064 & 0.002 & Supported \\
\hline Organizational citizenship behavior & $\leqslant=$ & Internal marketing & H9 & 0.324 & 0.102 & 0.001 & Supported \\
\hline Customer loyalty & $\leqslant=$ & Organizational citizenship behavior & H10 & 0.011 & 0.118 & $* * *$ & Supported \\
\hline
\end{tabular}

\subsection{Regression Analysis}

Linear regression analysis was performed using IBM AMOS edition 19 that helped in finding the link between dependent and independent variables [62]. The resulting outcomes are shown in Table 3 where all the hypothesis having $p$ value $<0.05$ are supported. It supported eight hypotheses which are H1, H2, H4, H5, H6, H8, H9, and $\mathrm{H} 10$.

H1 is "internal marketing has a significant positive affect on job satisfaction." Results suggest that there is highly significant relationship between internal marketing and job satisfaction with $p$ value $=0.00$. Hence it supports H1. These findings are consistent with the findings of many authors [20]. Service organizations strive hard to promote job satisfaction among its employee so in turn they can perform up to the customers' expectations. Telecom organizations in Pakistan have also invested great deal of human and financial capital in activities 
Table 3. Regression analysis.

\begin{tabular}{|c|c|c|c|c|c|c|c|c|}
\hline Mediating variables & Relation & & & Estimate & S.E. & C.R. & $p$ & Indirect effects \\
\hline \multirow{3}{*}{ Job satisfaction } & JS & $\leqslant=$ & IM & 1.077 & 0.095 & 11.281 & *** & \\
\hline & CL & $\leqslant=$ & JS & 0.208 & 0.135 & 2.545 & 0.024 & \\
\hline & CL & $\leqslant=$ & IM & 0.473 & 0.214 & 2.209 & 0.007 & 0.021 \\
\hline \multirow{3}{*}{ Affective commitment } & $\mathrm{AC}$ & $\leqslant=$ & IM & 0.821 & 0.084 & 9.805 & ${ }^{* * *}$ & \\
\hline & CL & $\ll=$ & AC & 0.113 & 0.155 & 2.728 & 0.016 & \\
\hline & CL & $\leqslant=$ & $\mathrm{IM}$ & 0.341 & 0.203 & 1.681 & 0.033 & 0.026 \\
\hline \multirow{3}{*}{ Organizational citizenship behavior } & ОСВ & $\leqslant=$ & IM & 0.543 & 0.077 & 7.039 & $* * *$ & \\
\hline & CL & $\ll=$ & ОСВ & 0.166 & 0.168 & 3.392 & 0.010 & \\
\hline & CL & $\ll=$ & IM & 0.284 & 0.183 & 1.555 & $* * *$ & 0.015 \\
\hline
\end{tabular}

*IM = internal marketing, JS = job satisfaction, AC = affective commitment, $\mathrm{OCB}$ = organizational citizenship behavior, CL = customer loyalty.

that promote internal marketing in order to maintain a pool of satisfied employees. Rigorous recruitment \& selection, strong superior-subordinate communication, long term focus on the training and development of the employees, employee recognition through rewards, employee participation and empowerment etc. are the various internal marketing tactics employed by telecoms service providers in Pakistan. These results thus imply that such internal marketing efforts promote job satisfaction among customer service employees.

H2 is "job satisfaction has a significant positive affect on customer loyalty." Results suggest that there is highly significant relationship between job satisfaction and customer loyalty with $p$ value $=0.04$. Hence it supports $\mathrm{H} 2$. The results indicate that customer service employees who are satisfied with their jobs tend to render services in a manner that improve their work performance. With improved levels of work performance, they would be able to meet the customer expectations in the best possible manner which is regarded by customers in terms of their loyalty towards the organization.

$\mathrm{H} 4$ is "job satisfaction has a significant positive affect on affective commitment." Results suggest that there is highly significant relationship between job satisfaction and affective commitment with $p$ value $=0.00$. Hence it supports H4. Lumley et al. [46] lately reported the same results. Customer service employees who are satisfied with their jobs would intend to stay within the organization as all their needs are properly catered by the organization. In regard to this sense of satisfaction and fulfillment, they develop feelings of attachment towards the organization that ultimately results in affective commitment.

H5 is "internal marketing has a significant positive affect on affective commitment." Results suggest that there is highly significant relationship between internal marketing and affective commitment with $p$ value $=0.00$. Hence it supports H5. Giving employees a vision to believe in, investing in their development and rewarding them for their efforts i-e practicing internal marketing develops very affirmative feelings for the organization among employees as they feel valued and more respected. These positive feelings build an emotional connection between the employees and organization that ultimately leads to long-term emotional commitment referred as affective commitment in this study.

H6 is "affective commitment has a significant positive affect on customer loyalty." Results suggest that the relationship between affective commitment and customer loyalty is significant with a $p$ value $=0.033$. Hence it supports H6. Allen \& Girsaffe, [32] also provided support for these results. These results suggest that if customer service employees are emotionally attached to the organization, they engage themselves in such behaviors and activities that benefit the organization. An affectively committed employee who gives the status of family to his organization would definitely work with more dedication to avoid any problems or mis-commitments. Such emotional feelings reflect in employees' behavior and performance which leads to customer loyalty. When a customer witness that an employee is dedicated in delivering the services, he/she develops loyalty towards the service provider.

H8 is "job satisfaction has a significant positive affect on organizational citizenship behavior." Results suggest that there is highly significant relationship between job satisfaction and organizational citizenship behavior 
with $p$ value $=0.02$. Hence it supports H8. These results are in line with the findings of Bateman and Organ [8]. If employees are highly satisfied with their jobs, they may be highly motivated to show helping behavior at their work place and more inclined towards altruistic actions [8]. Satisfied employees do not feel exploited, overburdened or mentally disturbed even if they are busy in their work. They feel pleased to come forward in hour of need even if they are not rewarded or paid for their extra efforts and work. Thus, it is right to infer that satisfied employees exhibit organizational citizenship behavior.

H9 is "internal marketing has a significant positive affect on organizational citizenship behavior." Results suggest that there is highly significant relationship between internal marketing and organizational citizenship behavior with $p$ value $=0.01$. Hence it supports H9. These findings are consistent with the findings of Seyed Javadin [6]. These results imply that any investment on the employees through adoption of internal marketing practices can enhance their performance even if it is extra-role behavior. The possible reason is that the employee's organizational citizenship behavior is the reflection of employer's efforts to facilitate employees in all the possible ways. Customer service employee's when witness that an organization is going an extra mile in its efforts to make customer care center a better workplace for them, the gratified employees in return go an extra mile to offer their assistance in matters such as helping co-workers, being less grumpy, staying positive etc.

H10 is "organizational citizenship behavior has a significant positive affect on customer loyalty."Results suggest that there is highly significant relationship between organizational citizenship behavior and customer loyalty with $p$ value $<0.00$. Hence it supports H10. Employees who exhibit organizational citizenship behavior make more efforts than are expected of them and therefore it is logical that they outperform in their efforts to serve the customers. When customers observe that customer service employees are making greater efforts in delivering the services, they become pleased and intend to persistently receive the services from the same service provider thus becoming loyal.

This analysis helped to find the significance of relationship between the independent and dependent variable.

\subsection{Mediation Analysis}

Table 4 present results of mediation analysis performed using bootstrapping technique. The individual direct and indirect effect of mediators was found in the relationship between internal marketing and customer loyalty. It supported three hypotheses which are H3, H7, and H11.

The direct effect between internal marketing and customer loyalty is significant having $p$ value $=0.007$ and the indirect effect of internal marketing on customer loyalty through job satisfaction has a $p$ value $=0.021$ which is significant. It proves the meditational effect of job satisfaction between internal marketing and customer loyalty. Hence it proved H3. These results suggest that the effects of internal marketing transfers to customer loyalty via job satisfaction i-e if the level of job satisfaction is higher among employees than internal marketingis more likely to enhance the loyalty among customers and vice versa. Any variations in the level of employee job satisfaction will vary the effect of internal marketing efforts on customer loyalty. For example, if customer

Table 4. Mediation analysis.

\begin{tabular}{|c|c|c|c|c|c|c|c|c|}
\hline Mediating variables & Relation & & & Estimate & S.E. & C.R. & $p$ & Indirect effects \\
\hline \multirow{3}{*}{ Job satisfaction } & JS & $\leqslant=$ & $\mathrm{IM}$ & 1.077 & 0.095 & 11.281 & $* * *$ & \\
\hline & CL & $\ll=$ & JS & 0.208 & 0.135 & 2.545 & 0.024 & \\
\hline & CL & $\leqslant=$ & IM & 0.473 & 0.214 & 2.209 & 0.007 & 0.021 \\
\hline \multirow{3}{*}{ Affective commitment } & $\mathrm{AC}$ & $\leqslant=$ & $\mathrm{IM}$ & 0.821 & 0.084 & 9.805 & $* * *$ & \\
\hline & CL & $\ll=$ & $\mathrm{AC}$ & 0.113 & 0.155 & 2.728 & 0.016 & \\
\hline & CL & $\leqslant=$ & IM & 0.341 & 0.203 & 1.681 & 0.033 & 0.026 \\
\hline \multirow{3}{*}{ Organizational citizenship behavior } & OCB & $\leqslant=$ & $\mathrm{IM}$ & 0.543 & 0.077 & 7.039 & $* * *$ & \\
\hline & CL & $\leqslant=$ & OCB & 0.166 & 0.168 & 3.392 & 0.010 & \\
\hline & CL & $\ll=$ & IM & 0.284 & 0.183 & 1.555 & $* * * *$ & 0.015 \\
\hline
\end{tabular}

${ }^{*} \mathrm{IM}=$ internal marketing, JS = job satisfaction, AC = affective commitment, OCB = organizational citizenship behavior, CL = customer loyalty. 
service employees are satisfied with some aspects of their job (such as pay and promotion) and dissatisfied with other aspects (such as supervisor), then it will lead to variations in the level of job satisfaction. Under such conditions the effect of internal marketing on customer loyalty will also vary accordingly.

The second proposed mediating variable between internal marketing and customer loyalty was "affective commitment." The direct effect between internal marketing and customer loyalty is significant having $p$ value $=$ 0.033 and the indirect effect of internal marketing on customer loyalty through affective commitment came out has $p$ value $=0.026$ which is significant. It proves the meditational effect of affective commitment between internal marketing and customer loyalty. Hence it proved H7. These results indicate that the impact of internal marketing transfers to customer loyalty through affective commitment. The employee who feels a sense of belonging towards the organization is more likely to be pleased with the internal marketing practices carried out in the organization and this emotional bonding of employee towards his organization leads him to perform in better way that result in customer loyalty. Thus employee affective commitment plays a role in reaping the benefits of internal marketing in the form of customer loyalty.

The third proposed mediating variable between internal marketing and customer loyalty was "organizational citizenship behavior.” The direct effect between internal marketing and customer loyalty is significant having $p$ value $=0.033$. The indirect effect of internal marketing on customer loyalty through organizational citizenship behavior has $p$ value $=0.015$ which is significant. It proves the meditational effect of organizational citizenship behavior between internal marketing and customer loyalty. Hence it proved H11. These results suggest that the effects of internal marketing transfer to customer loyalty via organizational citizenship behavior i-e if employees exhibit organizational citizenship behavior than internal marketing will affect customer loyalty to greater extent. The prominent logic behind this relationship is that when organizations go an extra mile in their efforts to please employees, the gratified employees in return go an extra mile in their efforts to serve the customers even if they have to perform beyond their formal expected role. Employees who exhibit organizational citizenship behavior will be gladly willing to give extra hours to work, overachieve in delivering services to the customers, offer help to the coworkers etc. Thus, internal marketing is an effective approach in making customers pleased and loyal when customer service employees exhibit organizational citizenship behavior.

\section{Discussions}

Every telecom organization in Pakistan has company owned customer care centers where customer care employees (also known as customer service officer or CSO) deliver services to the customers. CSOs directly interact with the customers and therefore play very critical role in generating customer responses towards the service proving organization. Realizing CSOs role importance, telecom organizations are indulged in internal marketing practices to keep its employees happy as study supports that the happiness of service employees leads to the happiness of customers [63]. This study has sought to examine the sequential flow of effects that links internal marketing to customer loyalty. The previous study linked internal marketing and service quality with organizational citizenship behavior as mediator [6]. However, the aim of this study was to empirically test a model linking internal marketing to customer loyalty with job satisfaction, affective commitment, and organizational citizenship behavior as mediators. The Eleven most important findings of this study are: first, internal marketing positively influences job satisfaction which is consistent with the findings of many authors [20]. Second, the relation between job satisfaction and customer loyalty is positive. Third, it has been established that job satisfaction plays mediating role in the relationship between internal marketing and customer loyalty. Fourth, job satisfaction influences affective commitment which is in line with the findings of [46]. Fifth, job satisfaction has a significant positive effect on organizational citizenship behavior which is consistent with the findings of Bateman and Organ [8]. Sixth, there exists positive association between internal marketing and affective commitment as previously suggested by Caruana \& Calleya [27]. Seventh, affective commitment enhances customer loyalty previously supported by Allen \& Girsaffe [32]. Eighth, it has been found that affective commitment plays mediating role in the direct relationship between internal marketing and customer loyalty. Ninth, internal marketing positively influences organizational citizenship behavior which is also reported by Seyed Javadin [6]. Tenth, the relationship between organizational citizenship behavior and customer loyalty is positive. Eleventh, organizational citizenship behavior plays mediating role in the relationship between internal marketing and customer loyalty.

In telecom sector of Pakistan where the experienced telecom organizations are indulged in internal marketing, the present study would offer some very useful insights. The results have shown that when a telecom organiza- 
tion made an investment in internal marketing, the pleased CSOs become highly satisfied with their jobs. High job satisfaction enhances their job performance and they deliver services in more efficient and effective manner. The effect of internal marketing varies towards the development of customer loyalty because of the variations in the level of employee job satisfaction. For example, if CSOs are satisfied with some aspects of their job (such as pay and promotion) and dissatisfied with other aspects (such as supervisor), then it will lead to variations in the level of job satisfaction. Under such conditions the effect of internal marketing on customer loyalty will also vary accordingly. CSOs who are highly satisfied with their jobs also become affectively committed towards the organization and exhibit organizational citizenship behavior. Internal marketing also contribute towards the employee affective commitment and organizational citizenship behavior. If a CSO is emotionally attached to the organization, he engages himself in such behaviors and activities that benefit the organization. His emotional feelings towards the organization reflect on his concern towards the organizational performance and he delivers services in a manner that please customers who in turn develop loyalty. The effects of internal marketing thus move towards customer loyalty via affective commitment. Similarly the effect of internal marketing transfers to customer loyalty via organizational citizenship behavior i-e if employees exhibit organizational citizenship behavior than internal marketing will affect customer loyalty to a greater extent. It has been suggested that when telecom organizations go an extra mile in their efforts to please employees, the gratified employees in return go an extra mile in their efforts to serve the customers even if they have to perform beyond their formal expected role. CSOs who exhibit organizational citizenship behavior will be gladly willing to give extra hours to work, overachieve in delivering services to the customers, offer help to the coworkers etc. Thus, internal marketing is an effective approach in making customers pleased and loyal when CSOs exhibit organizational citizenship behavior. Any variations in the level of organizational citizenship behavior among CSOs will vary the effect of internal marketing on customer loyalty. These complex relationships drive together in the same direction influences the customer loyalty among customers.

\section{Managerial Implications}

This study is significant for telecom service providers as it give insights about the organizational variables that play critical role in making customers' loyal. It suggests that internal marketing is very beneficial and effective approach towards the customer relevant behavioral outcomes in service organizations. The managers should devote special attention and resources towards the implementation of internal marketing in customer care centers as those employees who are highly satisfied with their jobs, affectively committed towards the organization and exhibit organizational citizenship behavior provide services in a way that please the customers. The pleased and gratified customers in turn become loyal towards the organization. Thus, managers must keep in mind that satisfied and affectively committed employees who exhibit organizational citizenship behavior may lead towards the customer loyalty.

\section{Conclusion}

This research work has been carried out in the customer care centers of telecom service providers in the main cities of Pakistan. Future research of the same type can be done in other service industries such as hotel industry, banking sector, courier service etc. Organizational citizenship behaviors are evaluated by asking the employee themselves and this approach might have influenced the relationships between studied variables. Relational variables such as relationship strength and relationship quality between the service exchange partners can be added in the existing model to observe their impact on the relationship between internal marketing and customer loyalty. The results of this study suit the cultural values and economy of Pakistan. The results may vary from culture to culture and economy to economy in other countries.

\section{References}

[1] Broady-Preston, J. and Steel, L. (2002) Employees, Customers and Internal Marketing Strategies in LIS. Library Management, 23, 384-393. http://dx.doi.org/10.1108/01435120210439861

[2] Khalid, Z. and Mughal, K. (2013) Analysis of the Internal Marketing Tactics Employed by Mobilink and Telenor. Universal Journal of Management and Social Sciences, 3, 1-15.

[3] Ahmed, P.K., Rafiq, M. and Saad, N.M. (2003) Internal Marketing and the Mediating Role of Organizational Competencies. European Journal of Marketing, 37, 1221-1241. http://dx.doi.org/10.1108/03090560310486960 
[4] Hogg, C. (1996) Selling Your Soul. Human Resources, 96, 88-90.

[5] Caruana, A., Ramaseshan, B. and Ewing, M.T. (1997) Does a Market Orientation Affect Organizational Commitment? In Harrison, J. and Nicholls, M.G., Eds., Innovation-New Products, Process and Techniques, Part II, 815-817.

[6] Seyed Javadin, S., Rayej, H., Yazdani, H., Estiri, M. and Aghamiri, S.A. (2012) How Organizational Citizenship Behavior Mediates between Internal Marketing and Service Quality: The Case of Iranian GAS Company. International Journal of Quality \& Reliability Management, 29, 512-530. http://dx.doi.org/10.1108/02656711211230508

[7] Angle, H.L. and Perry, J.L. (1981) An Empirical Assessment of Organizational Commitment and Organizational Effectiveness. Administrative Science Quarterly, 26, 1-14. http://dx.doi.org/10.2307/2392596

[8] Bateman, T.S. and Organ, D.W. (1983) Job Satisfaction and the Good Soldier: The Relationship between Affect and Employee Citizenship. Academy of Management Journal, 26, 587-595. http://dx.doi.org/10.2307/255908

[9] Williams, L.J. and Anderson, S.E. (1991) Job Satisfaction and Organizational Commitment as Predictors of Organizational Citizenship and In-Role Behavior. Journal of Management, 17, 601-657. http://dx.doi.org/10.1177/014920639101700305

[10] Macintosh, G. and Lockshin, L.S. (1997) Retail Relationships and Store Loyalty: A Multi-Level Perspective. International Journal of Research in Marketing, 14, 487-497. http://dx.doi.org/10.1016/S0167-8116(97)00030-X

[11] Spies, K., Hesse, F. and Loesch, K. (1997) Store Atmosphere, Mood and Purchasing Behavior. International Journal of Research in Marketing, 14, 1-17. http://dx.doi.org/10.1016/S0167-8116(96)00015-8

[12] Wong, A. and Sohal, A.S. (2006) Understanding the Quality of Relationship in Consumer Services: A Study in Retail Environment. International Journal of Quality \& Reliability Management, 23, 244-264. http://dx.doi.org/10.1108/02656710610648215

[13] Bitner, M.J. (1995) Building Service Relationships: It’s All about Promises. Journal of the Academy of Marketing Science, 23, 246-251. http://dx.doi.org/10.1177/009207039502300403

[14] Weatherrly, K.A. and Tansik, D.A. (1993) Managing Multiple Demands: A Role Theory Examination Behaviours of Customer Contact Service Workers. In: Swartz, T.A., Bowen, D.E. and Brown, S., Eds., Advances in Services Marketing and Management, Vol. 2, JAI Press, Greenwich, 279-300.

[15] Khalaf Ahmad, A.M. and Al-Borie, H.M. (2012) Impact of Internal Marketing on Job Satisfaction and Organizational Commitment: A Study of Teaching Hospitals in Saudi Arabia. Business and Management Research, 1, 82-94. http://dx.doi.org/10.5430/bmr.v1n3p82

[16] Sempane, M., Rieger, H. and Roodt, G. (2002) Job Satisfaction in Relation to Organizational Culture. SA Journal of Industrial Psychology, 28, 23-30. http://dx.doi.org/10.4102/sajip.v28i2.49

[17] Rajyalakshmi, N. and Kameswari, A.V. (2009) Internal Marketing for Customer Satisfaction in Retail Sector. AIMS Internal Journal of Management, 3, 207-220.

[18] Conduit, J. and Mavondo, F.T. (2001) How Critical Is Internal Customer Orientation to Market Orientation? Journal of Business Research, 51, 11-24. http://dx.doi.org/10.1016/S0148-2963(99)00044-2

[19] Iliopoulos, E. and Priporas, C.V. (2011) The Effect of Internal Marketing on Job Satisfaction in Health Services: A Pilot Study in Public Hospitals in Northern Greece. BMC Health Services Research, 11, 261. http://dx.doi.org/10.1186/1472-6963-11-261

[20] Al-Qudah, K.A.M., Mash, P. and Sherrihan, M. (2013) The Impact of Internal Marketing on Employees. Interdisciplinary Journal of Contemporary Research in Business, 4, 811-826.

[21] Schlesinger, L.A. and Zornitsky, J. (1991) Job Satisfaction, Service Capability, and Customer Satisfaction: An Examination of Linkages and Management Implications. Human Resource Planning, 14, 141-149.

[22] Schneider, B., Parkington, J.J. and Baxter, V.M. (1980) Employee and Customer Perceptions of Service in Banks. Administrative Science Quarterly, 25, 252-267. http://dx.doi.org/10.2307/2392454

[23] Schneider, B. and Bowen, D.E. (1985) Employee and Customer Perceptions of Service in Banks: Replication and Extension. Journal of Applied Psychology, 70, 423-433. http://dx.doi.org/10.1037/0021-9010.70.3.423

[24] Boulding, W., Kalra, A., Staelin, R. and Zeithaml, V.A. (1993) A Dynamic Process Model of Service Quality: From Expectations to Behavioral Intentions. Journal of Marketing Research, 30, 7-27. http://dx.doi.org/10.2307/3172510

[25] Mathieu, J.E. and Zajac, D.M. (1990) A Review and Meta-Analysis of the Antecedents, Correlates and Consequences of Organizational Commitment. Psychological Bulletin, 108, 171-194. http://dx.doi.org/10.1037/0033-2909.108.2.171

[26] Jenkins, M. and Thomlinson, R.P. (1992) Organizational Commitment and Job Satisfaction as Predictors of Employee Turnover Intentions. Management Research News, 15, 18-22. http://dx.doi.org/10.1108/eb028263

[27] Caruana, A. and Calleya, P. (1998) The Effect of Internal Marketing on Organizational Commitment among Retail Bank Managers. International Journal of Bank Marketing, 16, 108-116. http://dx.doi.org/10.1108/02652329810213510 
[28] Sergeant, A. and Frenkel, S. (2000) When Do Customer Contact Employees Satisfy Customers? Journal of Service Research, 3, 18-34. http://dx.doi.org/10.1177/109467050031002

[29] Ulrich, D., Halbrook, R., Meder, D., Stuchlik, M. and Thorpe, S. (1991) Employee and Customer Attachment: Synergies for Competitive Advantage. Human Resource Planning, 14, 89-103.

[30] Reichheld, F.F. (1996) The Loyalty Effect. Harvard Business School Press, Boston.

[31] McCarthy, D.C. (1997) The Loyalty Link. Wiley, New York.

[32] Allen, N.J. and Grisaffe, D.B. (2001) Employee Commitment to the Organization and Customer Reactions: Mapping the Linkages. Human Resource Management Review, 11, 209-236. http://dx.doi.org/10.1016/S1053-4822(00)00049-8

[33] Weaver, J.J. (1994) Want Customer Satisfaction? Satisfy Your Employees First. HR Magazine, 37, 93-95.

[34] Wang, H., Law, K.S., Hackett, R., Wang, D. and Chen, Z.X. (2005) Leader-Member Exchange as a Mediator of the Relationship between Transformational Leadership and Followers' Performance and Organizational Citizenship Behavior. Academy of Management Journal, 48, 420-432. http://dx.doi.org/10.5465/AMJ.2005.17407908

[35] Posdakoff, P.M., MacKenzie, S.B., Moorman, R.H. and Fetter, R. (1990) Transformational Leader Behaviors and Their Effects on Followers' Trust in Leader, Satisfaction, and Organizational Citizenship Behaviors. Leadership Quarterly, 1, 107-142. http://dx.doi.org/10.1016/1048-9843(90)90009-7

[36] Tepper, B.J. and Taylor, E.C. (2003) Relationships among Supervisors’ and Subordinates’ Procedural Justice Perceptions and Organizational Citizenship Behaviors. Academy of Management Journal, 46, 97-105. http://dx.doi.org/10.2307/30040679

[37] Organ, D.W., Podsakoff, P.M. and MacKenzie, S.B. (2006) Organizational Citizenship Behavior: Its Nature, Antecedents, and Consequence. Sage, Thousand Oaks.

[38] Konovsky, M.A. and Pugh, S.D. (1994) Citizenship Behavior and Social Exchange. Academy of Management Journal, 37, 656-669. http://dx.doi.org/10.2307/256704

[39] MacKenzie, S.B., Posdakoff, P.M. and Ahearne, M. (1998) Some Possible Antecedents and Consequences of In-Role and Extra-Role Salesperson Performance. Journal of Marketing, 62, 87-98. http://dx.doi.org/10.2307/1251745

[40] Grönroos, C. (1990) A Relationships Approach to Marketing: The Need for a New Paradigm. Working Paper 190, Swedish School of Economics, Helsinki.

[41] Berry, L. (1995) Relationship Marketing of Services. Growing Interest, Emerging Perspectives. Journal of the Academy of Marketing Science, 23, 236-245. http://dx.doi.org/10.1177/009207039502300402

[42] Gwinner, K.P., Gremler, D. and Bitner, M.J. (1998) Relational Benefits in Services Industries: The Consumer’s Perspective. Journal of the Academy of Marketing Science, 26, 101-114. http://dx.doi.org/10.1177/0092070398262002

[43] Zeithaml, V., Berry, L. and Parasuraman, A. (1996) The Behavioral Consequences of Service Quality. Journal of Marketing, 60, 31-46. http://dx.doi.org/10.2307/1251929

[44] Reichheld, F.F. (1993) Loyalty-Based Management. Harvard Business Review, 2, 64-73.

[45] Kotze, K. and Roodt, G. (2005) Factors that Affect the Retention of Managerial and Specialist Staff: An Exploratory Study of an Employee Commitment Model. SA Journal of Human Resource Management, 3, 48-55. http://dx.doi.org/10.4102/sajhrm.v3i2.65

[46] Lumley, E.J., Coetzee, M., Tladinyane, R. and Ferreira, N. (2011) Exploring the Job Satisfaction and Organizational Commitment of Employees in the Information Technology Environment. Southern African Business Review, 15, 100118.

[47] Spector, P. (2008) Industrial and Organizational Behavior. 5th Edition, John Wiley \& Sons, New Jersey.

[48] Robinson, S. and Morrison, E. (1995) Psychological Contracts and OCB: The Effects of Unfulfilled Obligations on Civic Virtue Behavior. Journal of Organizational Behavior, 16, 289-298. http://dx.doi.org/10.1002/job.4030160309

[49] Homburg, C. and Stock, R.M. (2004) The Link between Salespeople's Job Satisfaction and Customer Satisfaction in a Business-to-Business Context: A Dyadic Analysis. Journal of the Academy of Marketing Science, 32, 144-158. http://dx.doi.org/10.1177/0092070303261415

[50] Foreman, S.K. and Money, A.H. (1995) Internal Marketing: Concepts, Measurement, and Application. Journal of Marketing Management, 11, 755-768. http://dx.doi.org/10.1080/0267257X.1995.9964388

[51] Spector, P. (1997) Job Satisfaction: Application, Assessment, Causes and Consequences. Sage, California.

[52] Meyer, J.P. and Allen, N.J. (1997) Commitment in the Workplace: Theory, Research and Application. Sage, Thousand Oaks.

[53] Netemeyer, R., Boles, T.S., Mckee, D.O. and McMurrian, R. (1997) An Investigation into the Antecedents of Organizational Citizenship Behaviors in a Personal Selling Context. Journal of Marketing, 61, 85-98.

http://dx.doi.org/10.2307/1251791 
[54] Posdakoff, P.M. and MacKenzie, S.B. (1994) Organizational Citizenship Behaviors and Sales Unit Effectiveness. Journal of Marketing Research, 31, 351-363. http://dx.doi.org/10.2307/3152222

[55] Yoon, M.H. and Suh, J. (2003) Organizational Citizenship Behaviors and Service Quality as External Effectiveness of Contact Employees. Journal of Business Research, 56, 597-611. http://dx.doi.org/10.1016/S0148-2963(01)00290-9

[56] Hair Jr., J.F., Black, W.C., Babin, B.J., Anderson, R.E. and Tatham, R.L. (2006) Multivariate Data Analysis. 6th Edition, Prentice Hall, New Jersey.

[57] Wind, Y. and Saaty, T.L. (1980) Marketing Applications of the Analytic Hierarchy Process. Management Science, 26, 641-658. http://dx.doi.org/10.1287/mnsc.26.7.641

[58] Forman, E. and Gass, S. (2001) The Analytic Hierarchy Process-An Exposition. Operations Research, 49, $469-486$. http://dx.doi.org/10.1287/opre.49.4.469.11231

[59] Shokrkon, H. and Naami, A. (2009) Archive of SID the Relationship of Job Satisfaction with Organizational Citizenship Behaviour and Job Archive of SID.

[60] González, J.V. and Garazo, T.G. (2006) Structural Relationships between Organizational Service Orientation, Contact Employee Job Satisfaction and Citizenship Behaviour. International Journal of Service Industry Management, 17, 23-50. http://dx.doi.org/10.1108/09564230610651561

[61] Martinez, J.M., Stinson, J.L. and Jubenville, C.B. (2011) Internal Marketing Perceptions in Intercollegiate Athletics and Their Influence on Organizational Commitment. Journal of Issues in Intercollegiate Athletics, 4, 171-189.

[62] Hooper, D., Coughlan, J. and Mullen, M. (2008) Structural Equation Modeling: Guidelines for Determining Model Fit.

[63] Heskett, J.L., Sasser Jr., W.E. and Schlesinger, L.A. (1997) The Service Profit Chain: How Leading Companies Link Profit and Growth to Loyalty, Satisfaction and Value. Free Press, New York. 